\title{
DISSOLUÇÃO E TRANSFORMAÇÃO DA ORDEM EM "A NATUREZA, EM OPOSIÇÃO À GRAÇA”, DE RUBEM FONSECA
}

Carine Maria Angst ${ }^{1}$

Dionei Mathias ${ }^{2}$

Resumo Este artigo tem como foco de análise o conto "A natureza, em oposição à graça", parte da coletânea Secreções, Excreçẽes e Desatinos, publicada por Rubem Fonseca. Para isso, procura refletir como conceitos fundamentais da teoria pós-moderna têm um impacto na configuração acional do conto e no modo como as personagens são caracterizadas. Nesse horizonte, a primeira parte discute a dissolução da ordem herdada e as transformações de identidade de Ricardo e Sérgio, enquanto a segunda se volta para a instalação de uma nova ordem, marcada por elementos do grotesco. Sem oferecer respostas definitivas, o conto convida a reflexões sobre a condição humana que oscila entre natureza e graça.

Palavras-chaves: Rubem Fonseca. "A natureza, em oposição à graça". Pós-modernidade. Identidade. Grotesco.

\section{DISSOLUTION AND TRANSFORMATION OF ORDER IN RUBEM FONSECA'S “A NATUREZA EM OPOSIÇÃO À GRAÇA"}

\begin{abstract}
This article aims to analyse the short story "A natureza, em oposição à graça", part of the collection Secreções, Excreções e Desatinos, published by Rubem Fonseca. For this purpose, it tries to reflect on how fundamental concepts of postmodern theory have an impact on the configuration of action of this story and on the way the characters are designed. With this in mind, the first part discusses the dissolution of the inherited order and the transformations of identity in Ricardo and Sérgio, while the second part turns its focus to the installation of a new order, marked by elements of the grotesque. Without offering definitive answers, the story invites reflections on the human condition that oscillates between nature and grace.
\end{abstract}

Keywords: Rubem Fonseca. "A natureza, em oposição à graça". Postmodernity. Identity. Grotesque.

1 Mestrando em Letras, Universidade Federal de santa Maria (UFSM). E-mail: carine.angst@gmail.com .

2 Docente do Programa de Pós-graduação em Letras (UFSM), doutorado em Letras pela Universidade Federal do Paraná (UFPR). E-mail: dioneimathias@gmail.com 


\section{Introdução}

"A natureza, em oposição à graça" é um dos contos que constitui originalmente a coletânea de contos Secreções, Excreções e Desatinos, de Rubem Fonseca, publicado em 2001. Rubem Fonseca é um renomado escritor brasileiro, nascido em 1925, em Juiz de Fora, Minas Gerais. Ganhou vários prêmios literários, entre eles a Coruja de Ouro, o Kikito do Festival de Gramado, o Prêmio Jabuti e o Prêmio Camões. Dentre suas publicações estão os romances Agosto (1990), O caso Morel (1973) e coletâneas de contos como em Feliz. Ano Novo (1975) e O Cobrador (1980). O escritor faleceu vítima de um ataque cardíaco em 15 de abril de 2020, no Rio de Janeiro.

O conto "A natureza, em oposição à graça", narrado em primeira pessoa, conta a história do narrador-personagem e protagonista Ricardo que, inicialmente, representa um indivíduo civilizado, respeitoso, estudioso, trabalhador, de corpo delgado e que demonstra estar temeroso de perder a namorada Alessandra para Sérgio. Sérgio, ao contrário de Ricardo, é musculoso, não trabalha e nem estuda e sugere ser pouco inteligente, apesar de ser considerado corajoso. Além disso, os pais de Alessandra gostavam muito de Ricardo por respeitar sua filha, embora fosse vegetariano e não pudesse provar os pratos de sua sogra, Dona Lurdinha, que era cozinheira.

Toda essa estrutura começa a ser abalada quando Ricardo se incomoda com um comentário de sua namorada a respeito de Sérgio ao falar que ele "tinha cílios lindos" (FONSECA, 2010, p. 33). É nessa altura do conto que aparece Victor que defende a ideia de que o narrador-personagem é medroso e submisso pelo fato de não ingerir carne. Depois de ocorrer tudo o que Ricardo mais temia, quando Alessandra confessa que o traiu com Sérgio, o narrador-personagem resolve seguir os conselhos de Victor e decide ingerir sangue para tornar-se corajoso e destemido para enfrentar seu inimigo Sérgio. Após ingerir sangue bovino, diariamente por trinta dias e ainda não obter o resultado esperado, o narrador-personagem busca novamente os conselhos de Victor. Ele orienta Ricardo a beber o sangue do inimigo, a fim de que logo se efetivasse o que tanto almejava e para que nunca mais tenha medo de nada.

A intensa recepção da obra literária de Rubem Fonseca revela o quanto ela convida à reflexão e o quanto ela impõe desafios ao ato da leitura. Talvez seja possível aproximar-se dessa complexidade a partir daquilo que Lyotard (2009) denomina de fim dos metarrelatos, uma característica predominante na experiência pós-moderna. A partir do horizonte do pós-estruturalismo francês, Lyotard sustenta que muitas metanarrativas de legitimação caem em desuso e "a função narrativa perde seus atores, os grandes heróis, os grandes perigos, os grandes périplos e o grande objetivo" (LYOTARD, 2009, p. 16). As grandes narrativas perdem seu potencial de norteamento e a universalidade da verdade começa a se desintegrar (LYOTARD, 2009). Essa característica parece se consolidar no conto "A natureza, em oposição à graça”, uma vez que os personagens masculinos passam por um processo de dissolução das narrativas norteadoras, adotando novas malhas de sentido que orientam suas ações. Isso também se revela no plano do fazer diegético, onde surge uma ruptura com a estrutura de vilão e mocinho que de alguma forma fornecia até então vetores de estabilidade, agora deixando o leitor sem um norte claro.

Jameson (2000), sob uma perspectiva marxista, também defende a proposição de que o pós-modernismo desconstruiu as grandes narrativas. Para ele, o pós-modernismo, tanto na arquitetura, literatura e nas artes visuais, apresenta um descentramento/fragmentação do sujeito, em que prevalecem as tessituras das aparências. Desse modo, temos uma representação de ausência de 
sentido e perda do si, em que o sujeito abandonou, de certa forma, os nexos históricos do tempo e do espaço. Com efeito, o sujeito perde sua profundidade ao imergir numa cadeia de significantes desconexos. Enquanto Lyotard defende a renúncia ao princípio do consenso, preferindo a unicidade da paralogia, Jameson revela, em sua discussão, um anseio por uma nova cartografia do espaço que permita, de alguma forma, reaver uma estrutura teleológica estabilizante. $\mathrm{O}$ conto parece oscilar entre esses dois polos: por um lado a dissolução das narrativas norteadores, por outro, o anseio por um novo mapa de orientação que supra as necessidades dessa perda.

Linda Hutcheon (1991), em seu livro A poética dopós-modernismo, explica que não há consenso sobre data de início e fim, características definitórias ou textos considerados paradigmáticos do assim chamado pós-modernismo. A autora identifica uma mudança, no período que se estende do pós-guerra aos dias atuais, em que o convívio em sociedade se transformou de forma simbólica, econômica e interacional, consolidando uma fase capitalista, individualista e muito mais virtual. Nessa esteira, se fortalece o que ela denomina de poética do pós-modernismo, sem identificar nele um atributo constante e fixo: “[...] em minha opinião, o pósmodernismo é um fenômeno contraditório, que usa e abusa, instala e subverte, os próprios conceitos que desafia" (HUTCHEON, 1991, p. 19). Assim, por conferir novos sentidos a estruturas já consagradas, para depois questioná-las, seja na literatura, na escultura ou no cinema, o pós-modernismo vive do seu próprio questionamento. Essa dinâmica desestabilizadora do questionamento leva o leitor à autorreflexão sobre seu ser no mundo, à dúvida sobre verdades absolutas, mas também a uma atitude de ceticismo diante dos mecanismos da linguagem que condicionam o acesso à realidade. O conto de Rubem Fonseca parece trabalhar com essas contradições, a partir das transformações identitárias de Ricardo e Sérgio.

Muitos estudiosos chamam atenção para a estreita relação entre aquilo que se convencionou chamar de pós-modernismo e o período do modernismo que o antecede. Bauman (1999) assinala que a modernidade favoreceu o surgimento do imperativo da ordem - "a ordem do mundo, do hábitat humano, do eu humano e da conexão entre os três" (BAUMAN, 1999, p. 12). Bauman sustenta que a modernidade instaurou a oposição entre ordem e caos, em que uma precisa da outra para se conceber:

\begin{abstract}
A ordem como conceito, como visão, como propósito, só poderia ser concebida para o discernimento da ambivalência total, do acaso do caos. A ordem está continuamente engajada na guerra pela sobrevivência. $\mathrm{O}$ outro da ordem não é uma outra ordem: sua única alternativa é o caos. O outro da ordem é o miasma do indeterminado e do imprevisível. O outro é a incerteza, essa fonte e arquétipo de todo o medo. Os tropos do "outro da ordem" são: a indefinibilidade, a incoerência, a incongruência, a incompatibilidade, a ilogicidade, a irracionalidade, a ambiguidade, a confusão, a incapacidade de decidir, a ambivalência (BAUMAN, 1999, p. 14).
\end{abstract}

Nessa leitura, a modernidade se caracteriza pelo combate aos caos e à ambivalência, enfeixando seus esforços para a manutenção da ordem. A pós-modernidade, por sua vez, parece acolher a ambivalência e o caos, construindo suas visões de mundo a partir da alteridade que se desvela pela desordem e produzindo, com isso, uma intensificação da fragilização do sentido. Lyotard e Linda Hutcheon identificam nessa fragilização do sentido um fluxo com potencial inovador, Jameson, por sua vez, vislumbra um risco à estabilidade dos mapas que orientam a vida em sociedade. Os protagonistas do conto de Rubem Fonseca imergem nesse fluxo de dissolução dos sentidos, mas sem abdicar completamente ao anseio por uma ordem. 
No contexto da construção de identidade, os potenciais, mas também os riscos ficam especialmente claros. Por um lado a dissolução das macronarrativas tradicionais (nação, cultura, etnia, classe, sexualidade) abre um leque de possibilidades ao sujeito pós-moderno. Por outro, essa mesma dissolução o deixa sem um norte e o confronta com a necessidade de criar suas próprias narrativas individuais, ficando à mercê das inúmeras ofertas do mercado de identidade que a pós-modernidade disponibiliza. Alsina e Bravo (2006) defendem que a crise de identidade abre um leque de novas possibilidades: "La identidad como "totalidad" ya no es posible y hemos de aprender a convivir con nuevas formas fluidas, cambiantes - de identidades parciales y, quizá, ambiguas. La seguridad del futuro pasa necesariamente por aprender a convivir con la ambigüedad interna" (ALSINA; BRAVO, 2006, p. 130). Cabe perguntar em que medida o convívio com a ambiguidade, como os autores sustentam, é factível e suportável. O conto de Fonseca parece trazer provocações nesse sentido.

A partir desse horizonte, este artigo deseja refletir sobre as transformações identitárias que ocorrem na realidade diegética do conto. Com foco nos personagens Ricardo e Sérgio, a discussão recai sobre o modo como a ordem dos grandes relatos perde seu potencial de orientação, para ser trocada por uma outra forma de ordenar as ações da realidade diegética. Num segundo momento, o foco se volta para a nova ordem que se instaura na realidade diegética. Trata-se de uma ordem grotesca em sua natureza que parece remeter a uma nova forma de cartografar o espaço e combater o caos da desordem. Com isso, Rubem Fonseca confronta o leitor com um "fenômeno contraditório" que "instala e subverte" novas ordens, exigindo um esforço de decodificação por parte do leitor, sem instalar mecanismos diegéticos que suavizem os impactos da ambivalência.

\section{Dissoluções e transformações identitárias}

As novas formas de concretização do si, pautadas por complexas redes de informações mais móveis que nunca, convidam a problematizar a questão dos vínculos sociais e dos jogos de linguagem, abordados por Lyotard (2009). No conto, percebe-se que a identidade do narradorpersonagem, Ricardo, é influenciada por Victor, mas também por Sérgio que desperta nele o anseio por vingança. Desse modo, a voz narrativa dissolve paulatinamente seus vínculos sociais e passa a ter uma postura totalmente diversa à que defendia antes. Com efeito, Ricardo passa a adotar novos jogos de linguagens, criando novas configurações em sua narrativa identitária. Diametralmente, isso também ocorre com Sérgio. Inicialmente caracterizado como "brutamontes" (FONSECA, 2010, p. 34), ele começa a demonstrar mais respeito e consideração por Ricardo, quando passa a se relacionar com Alessandra, a ex-namorada de Ricardo. Em ambos os casos, ocorreu uma transformação no modo como organizam suas ações e suas redes teleológicas. Suas narrativas de identidade passam a ser pautadas por outros crivos de percepção ou modelos de concretização existencial. Essa transformação talvez possa ser compreendida como resultado do processo de dissolução das grandes narrativas:

Desta decomposição dos grandes Relatos,
[...], segue-se o que alguns analisam com a
dissolução do vínculo social e a passagem das
coletividades sociais ao estado de uma massa
composta de átomos individuais lançados
num absurdo movimento browniano. Isto
não é relevante, é um caminho que nos parece
obscurecido pela representacãa paradisiaca
de uma sociedade "orgañica" perdida.
(LYOTARD, 2009, p. 28)

Assim, com a dissolução dos pactos coletivos, o escopo de concretização da individualidade assume outras formas. O que define o modo 
como pensar e organizar a identidade em forma de narrativa não são mais os grandes relatos da emancipação, do progresso, do pensamento moral, mas sim o imperativo da individualidade, com seus desmandos egoístas. Isso obviamente não significa que esses grandes relatos desapareceram completamente, mas sua adoção como norte das ações passa por outros critérios de avaliação. O que antes era um imperativo passa a ser um mecanismo narrativo, dentre outros, a ser incorporado de acordo com as necessidades individuais.

A mudança da identidade de Ricardo e Sérgio parece ilustrar isso. O narrador-personagem que antes mantinha a convicção de que a civilidade o tinha poupado de uma vida medíocre e sem recursos, assumindo que isso favorecia a sociedade como um todo, se transforma ao ser confrontado com a força bruta de Sérgio. No período que antecede esse encontro, a VOZ narrativa parece acreditar nos grandes relatos da moral, da emancipação e do progresso, investindo para isso no princípio civilizatório. A experiência com a força bruta e sua animalidade, completamente desprovidas dessas metanarrativas, produz uma transformação. Ricardo passa a enxergar o mundo a partir de um crivo que mede forças e estabelece uma hierarquia de capital físico, sem qualquer atenção a preceitos morais. O conto parece encenar como o homem volta a ser o lobo do homem, um elemento que já figurara na coletânea Feliz, ano novo, de 1975.

Ao discutirem o conceito de identidade, Bauman e Hall revelam consenso sobre a convicção de que identidade já não é mais um fenômeno estável e definitivo. Segundo Bauman (2005, p. 22), "a fragilidade e a condição eternamente provisória da identidade não podem mais ser ocultadas", mesmo que esse seja um fato novo e muito recente. Hall (2006), por sua vez, defende que é característica intrínseca do sujeito pós-moderno possuir várias identidades contraditórias em um mesmo si:
Esse processo produz o sujeito pós-moderno, conceptualizado como não tendo uma identidade fixa, essencial ou permanente. [...] $\mathrm{O}$ sujeito assume identidades diferentes em diferentes momentos, identidades que não são unificadas ao redor de um "eu" coerente. Dentro de nós há identidades contraditórias, empurrando em diferentes direções, de tal modo que nossas identificações estão sendo continuamente deslocadas (HALL, 2006, p. 13).

Bauman e Hall, em grande parte, voltam seu olhar para as dimensões multiculturais da identidade no mundo globalizado. Por um lado, encontramse as narrativas identitárias fixas e estáveis, no seu arraigamento nas tradições culturais. Por outro lado, surgem as identidades pós-modernas com múltiplas afiliações, sem compromisso de fidelidade a uma narrativa única. Não é esse mundo globalizado que figura no conto de Rubem Fonseca, mas também ele cria uma realidade diegética, em que o si se desestabiliza, perdendo o elo sólido de afiliação às narrativas tradicionais que forneciam modelos identitários.

Olhando dessa perspectiva, o título do conto, "A natureza, em oposição à graça", é revelador. A graça parece remeter a esse mundo de outrora, em que o pacto civilizatório continha diretrizes de como pensar e concretizar a própria identidade. Em oposição à graça que transpira do projeto de emancipação, progresso e empatia, encontra-se a natureza como força e potencial de destruição. Essa natureza se assemelha ao caos, produzido pela fragilização da ordem que guiava a concretização existencial. $\mathrm{Na}$ discussão de Bauman, o caos e a desordem provinham da ambivalência que escapava ao jugo da ordem, contendo portanto conotações positivas. O que se encena no conto de Fonseca, por sua vez, parece remeter a uma outra dimensão do caos. Esse mesmo caos também origina de uma insubordinação à ordem, mas a ambivalência, com sua fluidez de narrativas identitárias, produzida por ele encena seu potencial de destruição, ao afiliar-se à força bruta. 
O conto, contudo, não oferece o caminho para uma nova ordem. Pelo contrário, o título condensa uma ambiguidade que cabe ao leitor processar semanticamente. Assim, não fica peremptoriamente definido se a "natureza" deve ser vista com simpatia, ao remeter a um corpo belo, ou com repulsa ao trazer a lume a força bruta (Sérgio). Tampouco fica claro se a "graça" que transpira do pensamento moral de Ricardo contém conotações positivas ou se ela encena uma visão de mundo ultrapassada, na era da performance. A essa ambiguidade, junta-se a fluidez das narrativas: o gracioso Ricardo do início se transforma num Ricardo animalizado (natural) na segunda parte. O Sérgio natural (animalizado) do início passa a adotar um comportamento gracioso, na segunda parte. Essas transformações parecem remeter a um complexo processo de dissolução dos dispositivos que, de alguma forma, orientavam as narrativas de identidade.

Para elucidar essa transformação de identidades de Ricardo e Sérgio, elaborou-se um quadro comparativo, em que inicialmente comparou-se a identidade caracterizada como humanizada de Ricardo com o comportamento animalizado de Sérgio. O segundo quadro ilustra o caminho inverso, já que agora Sérgio apresenta um comportamento humanizado e Ricardo um comportamento animalizado:

\begin{tabular}{|c|c|}
\hline \multicolumn{2}{|c|}{ Ricardo namora com Alessandra } \\
\hline $\begin{array}{c}\text { Ricardo } \\
\text { Comportamento gracioso } \\
\text { Corpo desgracioso }\end{array}$ & $\begin{array}{c}\text { Sérgio } \\
\text { Comportamento animalizado } \\
\text { Corpo gracioso }\end{array}$ \\
\hline $\begin{array}{l}\text { Tenho visto as ofensas que esse indivíduo lhe faz sempre } \\
\text { que vocês se encontram, notei o que aconteceu hoje na } \\
\text { piscina. Você, como fazem os cachorros medrosos ao } \\
\text { enfrentar um outro mais feroz, deitou-se submisso com o } \\
\text { rabo entre as pernas. (p. 33) }\end{array}$ & $\begin{array}{l}\text { Não esqueço aquele dia em que estava na beira da piscina, } \\
\text { sentado ao lado de Alessandra, deitada de biquíni numa } \\
\text { espreguiçadeira, quando Sérgio se aproximou e, antes que } \\
\text { eu pudesse fugir para a sauna, postou-se ao nosso lado, } \\
\text { olhando acintosamente o corpo da minha namorada. } \\
\text { Depois perguntou, não vai cair na água, ô raquítico? (p. 32) }\end{array}$ \\
\hline $\begin{array}{l}\text { Lamentava que o seu futuro genro não comesse os } \\
\text { melhores pratos que ela fazia, pois eu era vegetariano. } \\
\text { Dona Lurdinha perdoava-me essa excentricidade, como me } \\
\text { perdoava não ser doutor, e preparava-me iguarias especiais, } \\
\text { com verduras e legumes, pois eu era delicado, prestativo e } \\
\text { tratava bem sua filha. (p. 33) }\end{array}$ & $\begin{array}{l}\text { Ele sabia nadar, jogar tênis, lutar jiu-jítsu, eu não. Era } \\
\text { musculoso, eu não. (p. 32) }\end{array}$ \\
\hline $\begin{array}{l}\text { Qualquer outra pessoa teria me magoado com aquelas } \\
\text { palavras, mas o velho parecia um bruxo de história em } \\
\text { quadrinhos. Depois de ter dito que eu não passava de um } \\
\text { cão medroso, acrescentou que sabia por que eu não reagia } \\
\text { às provocações do outro (p. 33) }\end{array}$ & $\begin{array}{l}\text { A namorada que eu amava ia ficar à mercê daquele } \\
\text { brutamontes. (p. } 35 \text { ) }\end{array}$ \\
\hline $\begin{array}{l}\text { Aquela dieta cuidadosa à base de verduras havia feito de } \\
\text { mim um covarde? Não, eu era } \\
\text { apenas prudente, e as pessoas felizes eram prudentes, e a } \\
\text { prudência leva à previdência, e graças a isso eu escapara da } \\
\text { pobreza de minha infância. (p. 34) }\end{array}$ & $\begin{array}{c}\text { Como é que ele sabia que eu tinha sido um namorado } \\
\text { respeitoso? É duro, mas ele devia ter descoberto isso, que } \\
\text { eu era um namorado respeitoso, quando tirou a virgindade } \\
\text { de Alessandra, coisa que eu não fiz, apesar de ela ter pedido. } \\
\text { (p. 38) }\end{array}$ \\
\hline
\end{tabular}

\begin{tabular}{|c|c|}
\hline \multicolumn{2}{|c|}{ Sérgio namora com Alessandra } \\
\hline $\begin{array}{c}\text { Sérgio } \\
\text { Comportamento gracioso } \\
\text { Corpo civilizado }\end{array}$ & $\begin{array}{c}\text { Ricardo } \\
\text { Comportamento animalizado } \\
\text { Corpo incivilizado }\end{array}$ \\
\hline
\end{tabular}




\begin{tabular}{|c|c|}
\hline $\begin{array}{l}\text { A Alessandra me disse que você gosta de pescar, eu tenho } \\
\text { dois molinetes, vamos pescar um dia, juntos? Ele perguntou } \\
\text { amavelmente. (p. } 37 \text { ) }\end{array}$ & $\begin{array}{l}\text { Senti uma fraqueza invadir meu corpo } \\
\text { e cambaleando fui para o quarto, deitei-me, e logo o } \\
\text { orgulho de ter conseguido comer sangue me animou, o } \\
\text { enjoo desapareceu, meu corpo deixou de tremer.(p. 36) }\end{array}$ \\
\hline $\begin{array}{l}\text { Sérgio sempre me tratou com desprezo, mas nesse dia } \\
\text { mostrou-se respeitoso. Pediu o meu telefone quando nos } \\
\text { despedimos. (p. } 37 \text { ) }\end{array}$ & $\begin{array}{l}\text { Durante um mês segui com sacrifício a dieta do velho, } \\
\text { esperando conseguir ter coragem de desafiar o meu inimigo, } \\
\text { mas ainda sem forças para enfrentá-lo. (p. 36) }\end{array}$ \\
\hline $\begin{array}{l}\text { Pode contar comigo, respondeu Sérgio, já pescou à noite, de } \\
\text { cima de um penhasco? (p. 38) }\end{array}$ & $\begin{array}{c}\text { Chegando em casa liguei para Sérgio perguntando se ele } \\
\text { não queria pescar no fim de semana. (p. 37) }\end{array}$ \\
\hline $\begin{array}{l}\text { É um presente, ele disse, você merece, foi um namorado } \\
\text { respeitoso. (p. } 38 \text { ) }\end{array}$ & $\begin{array}{l}\text { Peguei a pedra e bati com força na cabeça de Sérgio. Ele } \\
\text { caiu, sangrando muito, e despencaria no precipício, se eu } \\
\text { não o } \\
\text { segurasse, colocando o meu corpo sobre o dele. (p. 38) }\end{array}$ \\
\hline & $\begin{array}{l}\text { Colei a boca no ferimento da cabeça de Sérgio, para sugar o } \\
\text { sangue que escorria. Não senti nenhum nojo, era como se } \\
\text { fosse suco de tomate. (p. 38) }\end{array}$ \\
\hline
\end{tabular}

Diante desses quadros comparativos, percebe-se que a identidade pacífica de Ricardo, pautada por princípios do pacto civilizatório, se fragmente, passando a adotar os componentes narrativos disponibilizados por Victor para concretizar sua identidade. A existência de Victor certamente é questionável, ele pode muito bem ser fruto da imaginação de Ricardo, permitindo que ele concretize o que antes sua afiliação ao pacto civilizatório não permitia verbalizar. Ao mesmo tempo, ele também pode representar o agente que disponibiliza narrativas identitárias sob medida, características da pós-modernidade e não mais afiliadas à tradição, sendo desenhadas de acordo com os objetivos individuais.

Sérgio, por sua vez, também modifica seu comportamento devido ao vínculo social que passa a ter com Alessandra. Após conquistar a mulher desejada, ele não precisa mais estabelecer hierarquias da força. A força bruta já prestou seus serviços para obtenção de satisfação, podendo então fazer as concessões que a vida em sociedade demanda. Na sua visão de mundo, as narrativas do pacto civilizatório não são realmente compulsórias. Elas passam a integrar sua concretização existencial por comodidade e pelo princípio do menor dispêndio de energia. Também neste caso ocorre uma transformação no modo como a narrativa de identidade passa a ser organizada, mas deixando claro que seu norte não reside em metarrelatos legados pela tradição, mas sim nas veleidades do indivíduo em busca de satisfação.

Em ambos os casos, o vínculo com as grandes narrativas enfraquece (Ricardo) ou era inexistente (Sérgio), desencadeando o caos na ordem que dispunha o convívio no espaço social da realidade diegética. A ambiguidade que desponta nessa nova configuração é combatida pela força bruta. Sérgio o faz para satisfazer seu desejo por Alessandra, Ricardo a adota para saciar seu anseio por vingança. Ambos revelam a instabilidade narrativa de suas identidades, as quais são modeladas de acordo com convicções pessoais e não mais por grandes narrativas do passado.

\section{O grotesco como nova ordem}

Em seu estudo, Kayser (2003) assinala que o grotesco, na sua origem, referia-se a um grupo de formas vegetais, animais e humanas que combinavam de uma maneira anormal e fantástica. $\mathrm{Na}$ época da Renascença, o grotesco ainda era 
relacionado a ornamentação lúdica e que ao mesmo tempo poderia representar o sinistro. Já no século XVI, passou a ser classificado como algo que ultrapassa a realidade e que representa um mundo diferente, criado pela imaginação dos pintores. É nessa época que o grotesco parte da Itália e vai impactar em países do norte da Europa, passando a ser utilizado no desenho, na gravura, na pintura e na arquitetura (ROSSI, 2010).

É no século XVII, que se encontra a definição do grotesco relacionado a mistura do animalesco, do humano e do monstruoso e que permite classificá-lo também como bizarro, ridículo, burlesco e cômico:

\begin{abstract}
Sempre associada ao disforme (conexões imperfeitas) e ao onírico (conexões irreais), a palavra "grotesco" presta-se a transformações metafóricas, que vão ampliando o seu sentido ao longo dos séculos. De um substantivo com uso restrito à avaliação estética de obrasde-arte, torna-se adjetivo a serviço do gosto generalizado, capaz de qualificar - a partir da tensão entre o centro e a margem ou a partir de um equilíbrio precário das formas figuras da vida social como discursos, roupas e comportamentos (SODRÉ; PAIVA, 2002, p. 30).
\end{abstract}

Como categoria estética o grotesco passa a ser considerado somente no século XVIII e apresentado como tal somente no século XIX. É durante a época do Romantismo, que na literatura, o grotesco aparece de forma mais evidente (ROSSI, 2010). Kayser (2003) sustenta que o grotesco foi desconsiderado, por muito tempo, pelos livros de estética como uma subclasse do cômico e, considerado, portanto, de mau gosto. Kayser (2003) ainda defende que o grotesco deve ser classificado como categoria estética pelo fato de apresentar um processo criativo, na medida que, algo que é considerado normal, subitamente, torna-se estranho e sinistro. $O$ repentino, a surpresa, o ridículo, o satírico e o cômico são todas características do grotesco e permite uma visão desorientada, caótica, ambígua sobre o mundo:
Grotesco é a sensibilidade espontânea de uma forma de vida. É algo que ameaça continuamente qualquer representação (escrita, visual) ou comportamento marcado pela excessiva idealização. Pelo ridículo ou pela estranheza, pode fazer descer ao chão tudo aquilo que a ideia eleva alto demais (SODRÉ; PAIVA, 2002, p. 39).

No mundo pós-moderno, a televisão é um dos meios de comunicação que aderiram ao grotesco para aumentar sua audiência, substituindo, assim, "valores éticos por emoções baratas e abjeções de toda ordem, privilegiando a óptica do grotesco" (ROSSI, 2010, p. 04). Dessa forma, segundo Sodré e Paiva (2002) parece que o grotesco instaurou um pacto simbólico que arranca o telespectador da sua estagnação e lhe dá um divertimento fácil.

Como vários estudiosos vêm mostrando, o grotesco tem um lugar importante na obra de Rubem Fonseca (PEREIRA, 2009; HOTT, 2015; BARROS, 2013). Isso também ocorre no conto em análise, onde o protagonista Ricardo passa a beber sangue bovino, para tornar-se mais corajoso e enfrentar seu inimigo. A sequência de ações e comportamentos concretizado por ele se enquadra ao que Kayser (2003) definiu como grotesco, em que algo dentro das normas dominantes, nesse caso o comportamento de Ricardo, repentinamente se altera, transformando-se em algo sinistro.

Assim, desesperado ao ser traído pela namorada, o narrador-personagem procura Victor, que relaciona a falta de coragem de Ricardo ao fato de ter passado grande parte de sua vida sem ingerir carne e lhe dá o seguinte conselho:

Só tem uma solução, meu jovem, o velho prosseguiu, você é um caso sério, para resolver o seu problema não adianta agora comer bifes grelhados, tem que beber sangue, os grandes guerreiros se fortaleciam para a guerra bebendo sangue, mas ninguém fala mais nisso, as pessoas pensam no sangue como um fluido vermelho com plasma e corpúsculos unicelulares que serve apenas para carregar oxigênio, nutrientes e doenças de um lado para o outro. Os barbeiros antigos, aqueles que faziam sangrias, entendiam mais de sangue do que os médicos e cientistas em geral, porque sabiam que sangue é para ser derramado (FONSECA, 2010, p. 35). 
Ricardo abandona as diretrizes de comportamento até então vigentes em sua existência e internaliza os preceitos oriundos desse novo vínculo social, indo à procura de sangue para consumir. Para isso, falta ao trabalho a fim de fazer a encomenda de "sangue de touro", num açougue (FONSECA, 2010, p. 36). Após o consumo regular de sangue coagulado durante um mês, percebese a transição no comportamento de Ricardo. A gestualidade contida e o comportamento empático se transforma numa nova forma de concretização do si:

\begin{abstract}
Ao voltar para minha casa coloquei o sangue num prato fundo, sentindo seu odor nauseabundo. Com uma das mãos apertei o nariz e com a outra enchi uma colher com aquela substância, mas não consegui levá-la à boca. Então pensei em Alessandra falando das pestanas de Sérgio e isso fez com que resolutamente enfiasse a colher na boca, sempre apertando as narinas com a outra mão, e depois de algumas rápidas mastigadas engoli a matéria repelente, suando, sentindo vontade de vomitar, o corpo tremendo. Senti uma fraqueza invadir meu corpo e cambaleando fui para o quarto, deitei-me, e logo o orgulho de ter conseguido comer sangue me animou, o enjoo desapareceu, meu corpo deixou de tremer (FONSECA, 2010, p. 36).
\end{abstract}

A descrição minuciosa dessa cena encena a mudança sinistra, por qual passa a identidade de Ricardo: primeiro o cheiro provoca-lhe náuseas, depois ao colocar a substância na boca, sua, sente tremores e tem vontade de vomitar. Por último, sente-se animado por experimentar coragem de fazer aquilo, de modo que os tremores e o enjoo desaparecem. Sem constatar resultados após a ingestão contínua por um mês e ainda temeroso da truculência física de Sérgio, Ricardo volta a procurar Victor, que lhe aconselha o seguinte: "Se você quer resultados a curto prazo, [...] tem que beber o sangue do inimigo e se precisar matar o inimigo para beber o sangue dele, mata o inimigo, o melhor é isso mesmo, matar o inimigo e beber o sangue dele, e depois comer a carne dele [...]" (FONSECA, 2010, p. 37). Impelido por essas recomendações, Ricardo toma uma atitude drástica e mata Sérgio com um golpe na cabeça:

Colei a boca no ferimento da cabeça de Sérgio, para sugar o sangue que escorria. Não senti nenhum nojo, era como se fosse suco de tomate. Sorvi o sangue dele durante uns dez minutos, enquanto sentia, com a ponta dos dedos, a sedosidade dos seus longos cílios. Depois eu o empurrei e ele rolou pela escarpa. Ouvi o ruído do corpo batendo na água, ao afundar (FONSECA, 2010, p. 38).

Ao não deixar o corpo cair na água para sorver o sangue de Sérgio e fortalecer-se com isso, Ricardo demonstra que segue rigorosamente os conselhos de Victor. A repugnância, o nojo e a ânsia ao ingerir o sangue, antes sentidas pelo narrador, desapareceram completamente. Uma nova visão de mundo se instalou em seu universo pessoal e essa visão de mundo já não hesita em adotar uma truculência ainda maior que aquela de seu rival. O que a caracteriza é justamente o grotesco, como descrito por Rosenfeld (1996, p. 61):

O fantástico, monstruoso, macabro, excêntrico,
obsceno invadem nossa realidade cotidiana, as
suas leis de repente estão suspensas, a ordem
habitual das coisas se desfaz. É daí, ante a
alienação surpreendente do nosso mundo que
decorre a reação de horror, espanto, nojo e,
por vezes, de riso arrepiado. Mesmo nos graus
atenuados do grotesco, de tipo mais lúdico
ou satírico, não podemos deixar de sentir
um ligeiro estremecimento, ante o espetáculo
descomunal de um mundo, cujas categorias
básicas perdem a sua validade.

Ricardo passa a concretizar um comportamento animalizado e grotesco, em que prevalece uma gestualidade predadora. A fragilização do pacto civilizatório, do qual era signatário até então, se revela ao não demonstrar qualquer arrependimento sobre as decisões tomadas por ele: "O laudo do legista registra que as pálpebras do morto foram arrancadas, disse o tira. [...] O tira olhou para mim, viu à sua frente um homem seguro e tranquilo" (FONSECA, 2010, p. 38). Essa transformação é igualmente identificável no modo como passa se relacionar com Alessandra, 
sua ex-namorada: "Alessandra me procurou, queria voltar a ser minha namorada. Levei-a para a cama umas duas vezes e depois tirei Alessandra e as verduras e legumes da sua mãe da minha vida. " (FONSECA, 2010, p. 39). A nova configuração de identidade também adota outra forma de enxergar a graça. A graça que se instala a partir do grotesco já não está mais relacionada ao comportamento ético que Ricardo trazia a lume, no início do conto. Perpassada pelo monstruoso, ela parece se revelar na capacidade de dissimulação e manipulação do outro. Nessa perspectiva, gracioso seria aquele que sacia seus impulsos, sem ser punido por isso, convidando o leitor a refletir também sobre as transformações do conceito de graça.

Nesse comportamento, figura uma mistura do animalesco, do sinistro e do monstruoso, que também se revela na configuração espacial, como mostra o estudo de Silva Júnior (2016). O alto do precipício, local que foi escolhido para a pescaria e para o assassinato, apresenta elementos que contribuem para a construção de uma atmosfera com elementos do monstruoso: uma noite escura, sem lua, a presença de uma pedra no local e um terreno inclinado que é dado como responsável pelo acidente de Sérgio. A transformação de espaços, em sua configuração de luz e escuridão, reforça a presença do grotesco, uma vez que o narrador-personagem primeiramente transita em um condomínio fechado, depois em açougues e, por fim, busca um precipício para concretizar o assassinato. Esse percurso espacial por qual o protagonista transita remete à sua transformação no que diz respeito à narrativa de identidade. Esses espaços, de certa forma, oferecem um novo mapeamento, como Jameson ainda almejava, mas o mapa de orientação que se desenha está longe dos projetos de emancipação e de progresso daquilo que se concebe como humanidade.

Tanto a figuração do espaço como a transformação identitária passam a assumir elementos do grotesco. Essa malha de sentidos que se condensa em volta do grotesco parece remeter à nova ordem que Ricardo internaliza, abandonando a estabilidade dos grandes relatos herdados do passado. Isso fica especialmente explícito no modo como administra seus vínculos sociais. Assim, o assassinato de Sérgio e a coisificação de Alessandra já não despertam qualquer sentimento de remorso. Essa nova ordem traz a lume uma outra forma de pensar a dissolução do projeto da Modernidade. Ela é ambígua, com foco no presente, se instala e se subverte, sem criar estabilidade. Esse elemento do instável se reforça pela impossibilidade de identificar, por exemplo, se o personagem Victor é real ou fruto de um impulso imaginário, desconexo da realidade (diegética). Ao contrário de muitos textos que comemoram a dissolução dos vetores da Modernidade, esse conto parece ilustrar também alguns perigos inerentes a essa nova ordem que orienta a construção de identidades.

\section{Considerações finais}

O conto "A natureza, em oposição à graça", de Rubem Fonseca abarca características da pósmodernidade por apresentar o fim dos metarrelatos, a fragmentação de sentidos e do si, o questionamento de verdades absolutas, a presença da ambiguidade e do caos. O narrador-personagem que inicialmente demonstra estar afiliado à ordem da emancipação e do progresso, característica do período moderno, acaba passando por um processo de dissolução dessas narrativas norteadoras, desembocando na instabilidade dos sentidos, típica da sociedade pósmoderna. As identidades encenadas no conto são ambíguas, fluidas e conflitantes. Ricardo e Sérgio modificam suas narrativas do si, reconfigurando também a forma como administram vínculos sociais. É possível identificar que os personagens são movidos por exigências individuais, quase narcisistas, e não mais por narrativas herdadas do passado. 
No lugar dos grandes relatos, instaura-se a presença do grotesco como nova ordem. $\mathrm{Na}$ esteira dessa nova configuração acional, Ricardo abandona os princípios de respeito, empatia e paz, adotando um comportamento pautado por violência e indiferença. Nesse comportamento, ele passa a assemelhar-se a Sérgio, cuja mudança não representa uma transformação real, vale ressaltar, pois sua truculência se encontra apaziguada momentaneamente, já que teve os anseios de suas pulsões eróticas e de agressividade satisfeitas por esse momento. Nos dois casos, instala-se a lei do mais forte, que se dissimula quando necessário, disseminando caos e ambiguidade, a fim de saciar as veleidades do si. Essa imagem do pós-moderno (ou de continuação do moderno se entendida como caminho à barbárie) possivelmente pode ser decodificada como alerta à fragmentação dos consensos macroculturais.

\section{Referências}

ALSINA, Miquel Rodrigo; BRAVO, Pilar Medina. Posmodernidad y Crisis de Identidad. Revista Científica de Información y Comunicación. Número 03. Sevilla: 2006. p. 125-146.

BARROS, FELLIPE ERNESTO. Entre excrementos e secreções: $O$ texto de Rubem Fonseca. 2013. 103 f. Dissertação (Mestrado em Letras e Lingüística). Universidade Federal de Alagoas, Maceió, 2013.

BAUMAN, Zygmunt. Identidade: entrevista a Benedetto Vecchi. Tradução de Carlos Alberto Medeiros. Rio de Janeiro: Jorge Zahar Ed., 2005.

Modernidade e Ambivalência. Tradução de Marcos Penchel. Rio de Janeiro: Jorge Zahar Ed., 1999.

FONSECA, Rubem. Secreções, Excreções e Desatinos. $2^{a}$ ed. Rio de Janeiro: Agir, 2010.
HALL, Stuart. A identidade cultural na pósmodernidade. Tradução de Tomaz Tadeu da Silva, Guaracira Lopez Louro. 11 ed. Rio de Janeiro: DP\&A, 2006.

HOTT, LUIS OTAVIO. Um oásis de horror: o grotesco em "Romance negro e outras histórias", de Rubem Fonseca'. 2015. 100 f. Dissertação (Mestrado em Estudos Literários) - Universidade Federal de Minas Gerais, Belo Horizonte, 2015.

HUTCHEON, Linda. Poética do PósModernismo: história, teoria, ficção. Tradução de Ricardo Cruz. Rio de Janeiro: Imago Ed., 1991

JAMESON, Fredric. Pós-modernismo: a lógica cultural do capitalismo tardio. Tradução de Maria Elisa Cevasco. São Paulo: Editora Ática, 2000.

KAYSER, Wolfgang. O grotesco. Tradução J. Guinsburg. São Paulo: Perspectiva, 2003.

LYOTARD, Jean-François. A condição pósmoderna. Tradução de Ricardo Corrêa Barbosa. 12 ed. Rio de Janeiro: José Olympio, 2009.

PEREIRA, VINICIUS CARVALHO. Literatura e abjeção: um estudo da imagem das fezes na obra de Rubem Fonseca. 2009. 131 f. Dissertação (Mestrado em Letras - Ciência da Literatura) Universidade Federal do Rio de Janeiro, Rio de Janeiro, 2009.

ROSENFELD, Anatol. Texto e Contexto. 5 ed. São Paulo: Editora Perspectiva, 1996

ROSSI, Elvio Antônio. Ensaio sobre o grotesco. HACER - História da arte e da cultura: Estudos e Reflexões. 2010 p. 01-05

SILVA JUNIOR, Cloves da. Violência e poder sob as perspectivas de gênero, marginalização e vingança em contos de Rubem Fonseca. Dissertação (Mestrado em Letras) - Universidade Federal de Goiás, Faculdade de Letras (FL), Programa de Pós-Graduação em Letras e Linguística. Goiânia, 2016. 
SODRÉ, Muniz; PAIVA, Raquel. O império do

grotesco. Rio de Janeiro, Mauad, 2002.

Submissão: novembro de 2020.

Aceite: abril de 2021. 